Alexey Ostrovsky

Maia Raphava

Tbilisi

satai@akauri.com

\title{
NOTES \\ ON GEORGIAN TRANSLATIONS \\ OF THE WORKS \\ OF NICETAS STETHATOS
}

\section{INTRODUCTION}

The recent publication of Epistle IX of Nicetas Stethatos to Basil the Monk $^{1}$ and the Georgian translations of works of Nicetas Stethatos that are included in Arsen Iqaltoeli's Dogmatikon ${ }^{2}$ constitute important milestones in scholarship on the works of Nicetas Stethatos as well as for studies of Byzantine literary works in general. Nevertheless, some questions still remain unanswered or without sufficiently detailed analysis. It is unclear, for instance, why there is such a significant difference between the date of the colophon of the Georgian manuscripts (1030) and the date that is accepted nowadays in the scientific literature as the time, when the collection of Stethatos' epistles had to have been composed (c. 1080). It is not clear whether Basil the Monk, the addressee of Epistle IX, is the same person as Basil the Sophist, the addressee of Epistles V-VIII. The reason for the difference between the names of the Sophist in the Greek and Georgian

(1) M. RAPHAVA, “Georgian Translations of Nicetas Stethatos's Epistles (According to Arsen Iqaltoeli's Dogmatikon) [with the editio princeps of a letter lost in Greek]," in: Georgian Christian Thought and Its Cultural Context. Memorial Volume for the 125th Anniversary of Shalva Nutsubidze (1888-1969), ed. by T. NutSubidze, C. B. Horn, B. Lourié, Leiden, 2014, pp. 244-282.

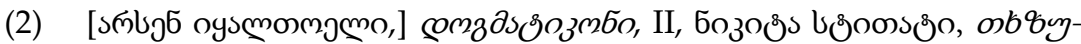

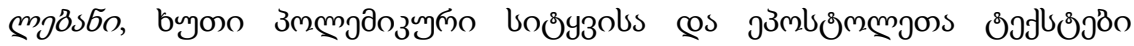

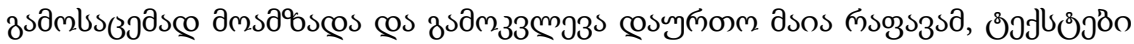

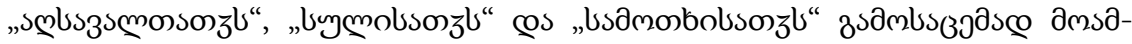

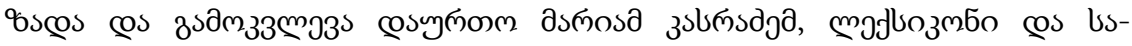

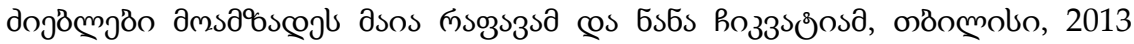
[[Arsen Iqaltoeli,] Dogmatikon: Nicetas Stethatos, Works, vol. II, ed. by M. RAPHAVA, M. KASRADZE, and N. CHIKVATIA, Tbilisi, 2013]. 
versions also remains obscure. The same is true for the question of why no Greek manuscripts contain Epistle IX that is preserved in the Georgian version. In this article we study these issues together with some minor questions. ${ }^{3}$

\section{TOWARDS A RELATIVE CHRONOLOGY OF NICETAS STETHATOS' EPISTLES}

According to subjects and dependencies, the treatises and the epistles of Stethatos can be grouped in three blocks:

- The first block includes the treatises "On the Soul" and "On Paradise," that had to have been written before any of the epistles.

- The second block includes (in chronological order):

a) Epistle $\mathrm{K}$ to Nicetas Chartophylax (also known as Nicetas Coronis), placed before both treatises, in which Stethatos presents the treatises to Chartophylax;

b) Epistle II to Nicetas Stethatos (Chartophylax' reply to Epistle $\mathrm{K}$ and the treatises); and

c) Epistle IV to Nicetas Chartophylax (Stethatos' reply to Epistle II).

(3) In addition to numbering the letters as Epistles I-IX, introduced by Jean Darrouzès (see below), we will use the following identifiers for the individual epistles:

- $\mathbf{K}$ for the stand-alone epistle to Nicetas Chartophylax (also known as

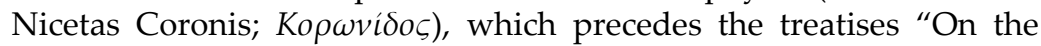
Soul" and "On Paradise";

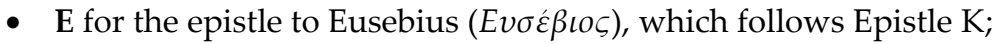

- *III for an epistle to Nicetas Stethatos by Nicetas Chartophylax, which is not preserved nowadays in full and is partly preserved as Epistle III. References to the epistles are provided in the format $E . n$, where $E$ is the identifier of the epistle (I-IX, $\left.{ }^{*} \mathrm{II}, \mathrm{K}, \mathrm{E}\right)$ and $n$ is a paragraph number (if there are paragraphs in the epistle).

Unless otherwise specified:

- Epistle IX (both Georgian and English versions) is quoted from RAPHAVA, "Georgian Translations";

- The Georgian text of Epistles K, E, I-VIII is quoted from Dogmatikon, II;

- Greek quotations are taken from Nicétas Stéthatos, Opuscules et lettres, introduction, texte critique, traduction française et notes par J. DARROUZES (SC 81), Paris: Cerf, 1961. 
- The third block includes (in chronological order):

a) Epistles V-IX to Basil by Nicetas Stethatos;

b) Epistle I to Nicetas Chartophylax, in which Stethatos presents his polemics with Basil; and

c) Epistle *III to Nicetas Stethatos (Chartophylax' reply to Epistle I), not known nowadays, which is partly preserved as Epistle III.

We do not have enough data to establish a reliable chronology for the whole set of epistles and treatises. Epistle $\mathrm{K}$ likely was sent before Epistle I, since Chartophylax should have been already familiar with the treatises in order to be able to read the polemics with Basil. Yet nothing more can be said with confidence about the relative chronology between the second and the third blocks. Thus, the mutual dependencies between the epistles and treatises of Nicetas can be summarized as follows: 4

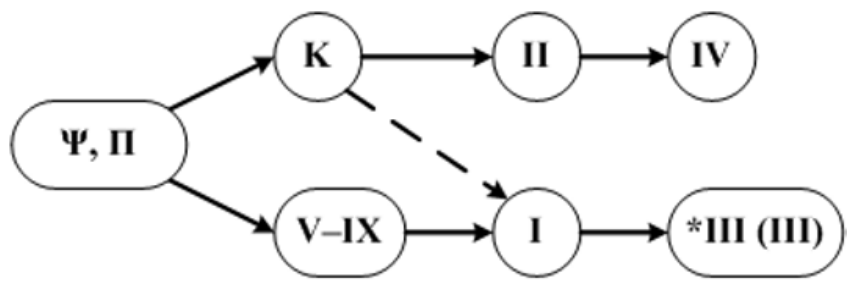

\section{DATE OF THE COLLECTION OF NiCETAS STETHATOS' WORKS}

The colophon in the Georgian manuscripts renders a date as follows:

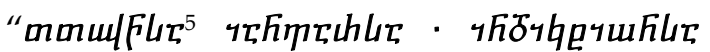

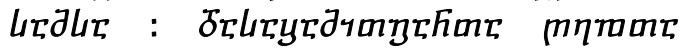
ЕФґю ::" in the month of January, third indiction, years from Creation $6538 .^{6}$

(4) Here we mark the treatises "On the Soul" and "On Paradise" as $\Psi$ ( $\Psi v \chi \eta ்)$ and $\Pi(\Pi \alpha \rho \alpha \delta \varepsilon \varepsilon \iota \sigma o \varsigma)$ respectively.

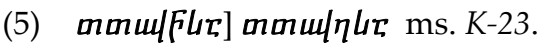

(6) National Centre of Manuscripts of Georgia, ms. S-1463, fol. 281rb; Kutaisi State Historical Museum, ms. K-23, fol. 335va. The orthography and the use of Asomtavruli and Nuskhuri scripts is the same in both manuscripts. 
The year AM 6538 of the Byzantine era ( $\kappa \alpha \tau \dot{\alpha}$ P $\omega \mu \alpha i o v \varsigma)$ corresponds to $1030 \mathrm{CE}, 7$ which differs significantly from the conclusion of Jean Darrouzès that the epistles should be dated circa 1080, or, at least, should fit the period of 1075-1090. ${ }^{8}$ Together with the year Anno Mundi, the colophon reports an indiction 3. Since in the Byzantine era an indiction number should be equal to the remainder from the division of the year Anno Mundi by $15,{ }^{9}$ the year AM 6538 corresponds to the indiction 13 and not 3 , specified in the colophon $(6538=15 \times 435+$ 13). Thus, there is an error in the colophon's date.

Here we should note that the date 1030 CE is unlikely, at least according to our current knowledge of the chronology of Nicetas Stethatos' life. Despite the general lack of clarity regarding the dates of his life, the year 1022 is accurately established as a reference point for Stethatos' youth, ${ }^{10}$ whereas the letters to Nicetas Chartophylax should be dated after 1050, because this date limits the known period of holding the office of chartophylax for the latter. ${ }^{11}$

It is possible that the colophon renders with error either the indiction year ( 3 instead of 13), or the year Anno Mundi. In order to stay within the range of the eleventh century (AM 6508-6607), which has to be sufficient to cover the time of Nicetas Stethatos' life, a conjecture for the AM year number is possible in the last two digits only. There is no possible conjecture for the last digit for the range of years from 6530-6539, which corresponds to the indiction number 3, while among the digits marking the position of tens, there are three corresponding dates: AM 6528, AM 6558, and AM 6588. Let us study each possible conjecture in detail.

Indiction 13 (AD 1030). Since the indiction number is written out in words, the conjecture in the Georgian version is not possible, be-

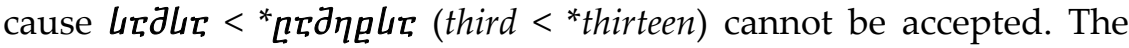

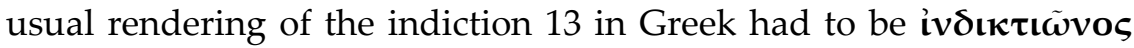

(7) V. GRUMeL, La Chronologie, Paris, 1958, pp. 128, 254; B. BLACKBURN, L. HOLFORD-STREVEnS, The Oxford Companion to the Year, Oxford, 1999, p. 766.

(8) Darrouzes, Opuscules et lettres, pp. 10, 24.

(9) Grumel, La Chronologie, p. 202; BlaCKBURN, Holford-Strevens, The Oxford Companion to the Year, p. 771.

(10) DarRouZES, Opuscules et lettres, p. 8.

(11) Ibid., pp. 17, 20. 
$\imath \gamma^{\prime}$, or IN $\Delta \mathfrak{t} \gamma^{\prime} . .^{12}$ In this case, we have to allow two assumptions at once to get Lrdur in the Georgian version: there had to have been an error in the Greek copies that would have led to the change of the indiction number $\left({ }^{*} \gamma^{\prime}<^{*}\left(\gamma^{\prime}\right)\right.$, and Arsen had to have changed the way an indiction was rendered. If the indiction number was written

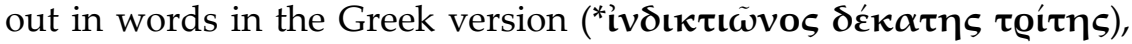
which is unusual, then the omission of tens should have resulted in

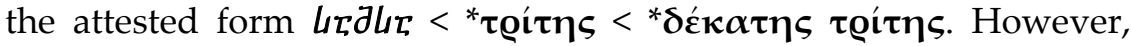
rendering the indiction number in words rather supports the initial

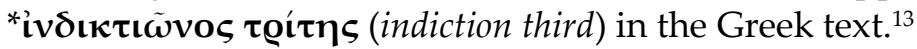

AM 6528, 6558, $6588(1020,1050,1080$ CE). Let us account for all the possible variants to render the appropriate dates Anno Mundi:

\begin{tabular}{|c|c|c|c|c|}
\hline & manuscript & AM 6528 & AM 6558 & AM 6588 \\
\hline $\begin{array}{l}\text { Georgian } \\
\text { Greek }\end{array}$ & 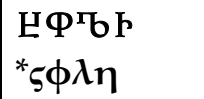 & $\begin{array}{l}{ }^{*} \mathrm{~L} \Phi \mathrm{q} \\
{ }^{*} \phi \phi \kappa \eta\end{array}$ & $\begin{array}{l}{ }^{*} \mathrm{~L} \Phi \mathrm{F} \text { } \\
{ }^{*} \phi \nu \eta\end{array}$ & $\begin{array}{l}{ }^{*} \mathrm{~L} \Phi U \mathrm{r} \\
{ }^{*} \phi \phi \eta\end{array}$ \\
\hline
\end{tabular}

The errors ${ }^{*} \mathbf{q}>\boldsymbol{} \mathbf{b}($ AM 6528$)$ and ${ }^{*} \boldsymbol{h}>\boldsymbol{} \boldsymbol{b}$ (AM 6558) in Georgian are hardly possible. The error ${ }^{*} U>\boldsymbol{} \times$ (AM 6588 ) is certainly possible for the second half of the eleventh century, especially in the case of Nuskhuri hands (the assumption that Arsen's protograph could have been written in cursive hand is quite plausible). ${ }^{14}$ The errors ${ }^{*} \kappa>{ }^{*} \lambda$ (AM 6528) and ${ }^{*} \pi>{ }^{*} \lambda$ (AM 6588) are hardly possible in Greek, whereas the error ${ }^{*} \boldsymbol{v}>^{*} \boldsymbol{\lambda}$ (AM 6558) is possible, but not likely. ${ }^{15}$

According to what is stated above, the possible retrieved dates of the colophon are $1080 \mathrm{CE}$ (AM 6588, most probable), $1050 \mathrm{CE}$ (AM 6558, less probable), or 1030 CE (AM 6538, unlikely). The most

(12) P. CANART, Lezioni di paleografia e di codicologia Greca, Citta del Vaticano, 1980, p. 96; Y. E. MEIMARIS, Chronological Systems in RomanByzantine Palestine and Arabia, Athens, 1992, p. 34.

(13) The rendering of an indiction number with words is not usual, and

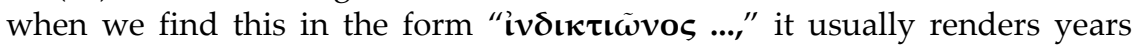
from 1 to 10 (see MEIMARIS, Chronological Systems, pp. 156-157, 162-304).

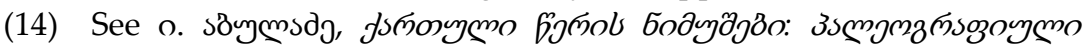
sмпனмдо, ов̈оmobo, 1973 [I. ABULADZE, Samples of Georgian Script: Paleographical Album, Tbilisi, 1973], pp. XI (col. 7-9), XII-XIII (col. 4-9).

(15) See V. GARDTHAUSEN, Griechische Paleographie, 2, Die Schrift, Unterschriften, und Chronologie im Altertum und im byzantinischen Mittelalter, Leipzig, 1913, Taf. 6-7. 
probable correction of the colophon's text (i. e. conjecture ${ }^{*} \mathrm{U} \Phi \mathrm{U} \mathrm{r}$ in the Georgian version) fits the expected period of 1075-1092.

Thus, we assume that the conjecture ${ }^{*} U>\boldsymbol{} b$ for the Georgian colophon is plausible, the Georgian protograph initially rendered the year Anno Mundi as ${ }^{*} \mathrm{E} \Phi \mathrm{U}$, and the correct date of the colophon is AM 6588, i.e. January of $1080 .{ }^{16}$

\section{The COLOPHON AND MARginal NOTE}

\subsection{The Colophon}

Here we would like to clarify one detail concerning the attribution of the colophon of the Georgian version. In all the Georgian manuscripts of the Dogmatikon the colophon has exactly the same marginal note:

“ozon saol mon̆lols dsaobs, uszoobszons sasom zsamajơ̊gy-

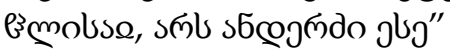

"This addition belongs to this honorable father himself, to the author of these readings" 17

The Georgian word zsamajosymb3mo (literally: one who says out loud, "teller") does not refer to just the author, but to the person, who actually articulates a phrase or speech. ${ }^{18}$ In the Georgian text

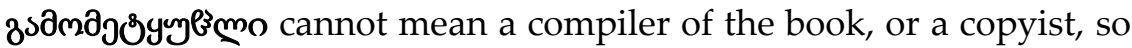
the author of the note (Arsen?) directly points us to the fact, that the author (teller) of the epistles and the trilogy and the author of the colophon is the same person (i. e. Nicetas Stethatos).

\subsection{The Marginal Note}

After analyzing the Dogmatikon manuscripts K-23 and S-1463 we came to the preliminary conclusion, that they are independent and ascend to a common protograph. At the time of its initial description,

(16) GRuMEL, La Chronologie, p. 128.

(17) Ms. S-1463, fol. 281r; ms. K-23, fol. 335v; the same marginal note is present in later copies - ms. Q-50 (1777, National Centre of Manuscripts of Georgia) and ms. K-15 (17 ${ }^{\text {th }}-18^{\text {th }}$ centuries, Kutaisi State Historical Museum).

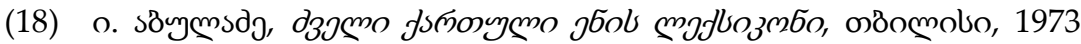
[I. ABUladze, Dictionary of Old Georgian Language, Tbilisi, 1973], p. 43; d3วलmo

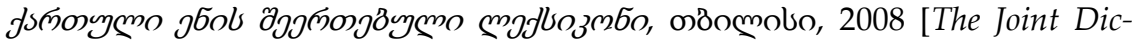
tionary of Old Georgian, Tbilisi, 2008], pp. 47-48. 
S-1463 was widely dated to the twelfth-thirteenth century. ${ }^{19}$ This question requires further detailed research, yet based on paleographical data we think that the manuscript S-1463 has to be dated preliminarily to the beginning of the twelfth century. ${ }^{20}$ According to this assessment, a common protograph of the manuscripts S-1463 and K-23 should be chronologically very close to the autograph of the Dogmatikon, and it is unlikely that there was a considerable written tradition between the Dogmatikon autograph and the common protograph of the manuscripts K-23 and S-1464. Thus, the protograph had to have been either one of the first copies from the Dogmatikon autograph, or the autograph itself. ${ }^{21}$

Since the marginal comment is attested in all the Georgian manuscripts of the Dogmatikon, it should go back at least to a common protograph of K-23 and S-1463. The fact, that this marginal note is rendered in the same form in all the Georgian copies (including the ones from a later period) supports the assumption that the marginal note itself is an integral part of the Dogmatikon, and its author is Arsen Iqaltoeli himself.

\subsection{The Purpose of the Marginal Note}

The date in the colophon by Nicetas Stethatos perfectly matches the format that is typical for colophons of copyists (month, indiction number, and year Anno Mundi). ${ }^{22}$ Thus, the purpose and necessity of the marginal note by Arsen Iqaltoeli are obvious: Arsen required it to indicate to his future readers that the colophon does not belong to the author of the Dogmatikon or one of its copyists, as one can assume

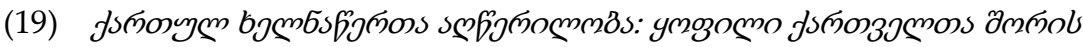

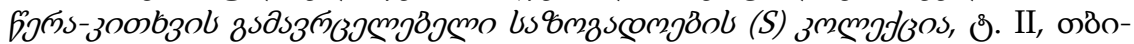
molon, 1961 [Description of Georgian Manuscripts: The Collection of the Society for the Spreading of Literacy among Georgians (S), II, Tbilisi, 1961], p. 213.

(20) The hand of S-1463 reveals similarity with hands from the $11^{\text {th }}$ century, in particular to the hand of ms. Q-37 (1091, National Centre of Manuscripts of Georgia). Cf. I. ABULADZE, Samples, Tab. XII-XIII, 106-109. An article by Alexey Ostrovsky on the dating of S-1463 is to be published in Mravaltavi (a journal of the National Centre of Manuscripts of Georgia).

(21) The final decision on this question depends on the results of the detailed study of the S-1463 and K-23 manuscripts and the relations between them.

(22) B. M. MetZger, Manuscripts of the Greek Bible: An Introduction to Greek Palaeography, New York, 1991, p. 49. 
from the form of the colophon, but instead belongs to the author of the text himself.

\section{ARe Both Basils the SAMe?}

Could it be the case, that the addressee of Epistles V-VIII and the one of Epistle IX is the same person? After a critical revision of the available evidence, we came to the conclusion that most probably Basil the Monk was the same person as Basil the Sophist.

\subsection{A Reference to Epistle IX in Epistle III}

In Epistle I, Nicetas Stethatos wrote to Chartophylax:

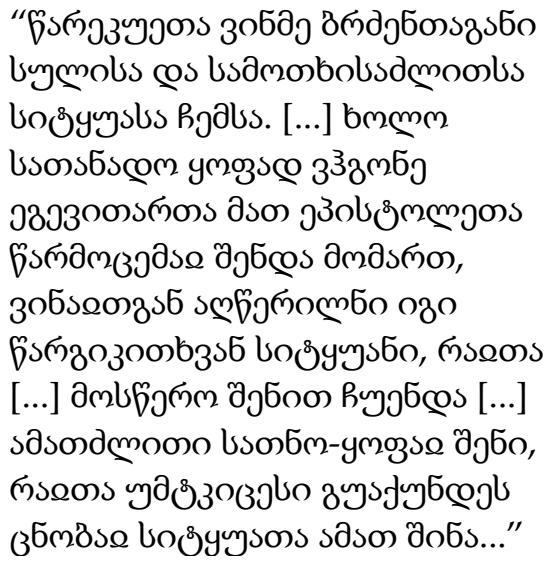

"Somebody from the wise ones was unhappy with my speeches on the soul and on paradise. [...] And I realized that it is necessary to send those epistles to you, so you will read the words written there, that $[\ldots]$ you would write us [...] your decision on them, so we would have an opinion of greater authority on the contents of those speeches." (I)

Answering to Stethatos in Epistle III, Nicetas Chartophylax wrote that he read the letters to the Sophist about paradise and the souls, residing in paradise (III.1), about the deacon's words "The doors, the doors!" (III.2), and about the apostle's words from 1 Cor 6:18 (III.3):

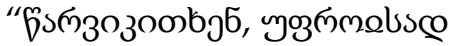

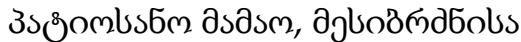

asluomolanasmonбogs

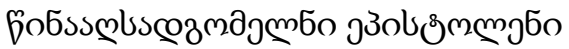

aj66o bsamonbolsonzl cos buymons sf

jnolơ

ymozolsonzl sos djäozmans..."
}

"I also read, oh highly
honorable father, your
objective letters to the
sophist Basil on paradise
and on the souls, residing
in paradise with Christ,
and others..." (III.1)




\begin{tabular}{|c|}
\hline 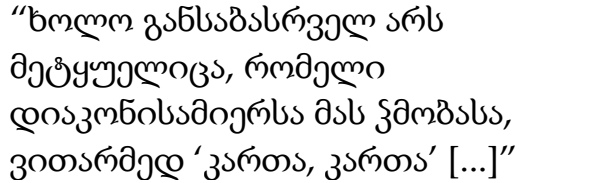 \\
\hline 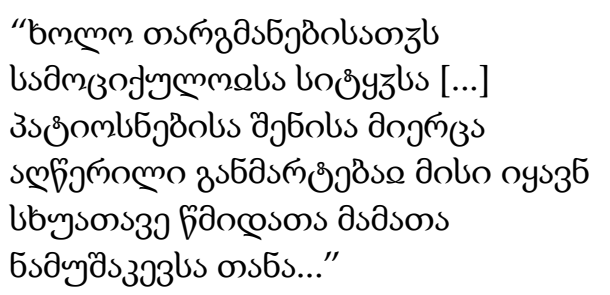 \\
\hline
\end{tabular}

"One, who says, that the deacon's words 'The doors, the doors!' [...] is worth of derision." (III.2)

"What about the treatment of the apostle's words [...] the elucidation written by Your Excellency will also take its place among the works of other holy fathers." (III.3)

There are no signs of a shift of subject or person being discussed in the letter by Chartophylax, which means that Chartophylax discussed Epistles VI, VII, VIII, and IX in the context of Stethatos' epis-

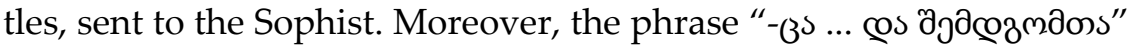
("also ..., and others <the following ones $>$ ") in the Georgian version of III.1, which is absent in Greek, clearly indicates, that the introductory phrase III.1 also refers to the epistles, mentioned in the following paragraphs III.2 and III.3.

Thus, according to Nicetas Chartophylax, the "objective letters to the sophist Basil" include epistles to both Basil the Sophist and Basil the Monk, as they do not only include the epistles on paradise (Epistle VI) and on the souls, residing in paradise (Epistle VII), but also the explanation of the deacon's words "The doors, the doors!" (Epistle VIII), and the explanation of 1 Cor 6:18 (Epistle IX). ${ }^{23}$

\subsection{The Arrangement of Nicetas Stethatos' Works in the Dogmatikon}

The titles of Nicetas Stethatos' works are rendered in the Dogmatikon as follows: ${ }^{24}$

(23) Epistle III exists in fragments only both in Georgian and Greek versions. We discovered another Georgian version of Epistle III, which differs from the known editions and allows us to establish a more complete version of Epistle III. We plan to publish the article on this new data as a follow-up to this article.

(24) Dogmatikon, II, pp. 6-7. 


\begin{tabular}{|c|}
\hline 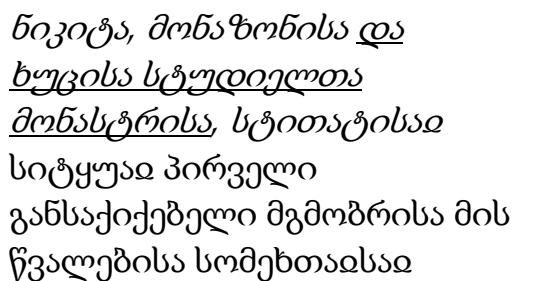 \\
\hline
\end{tabular}

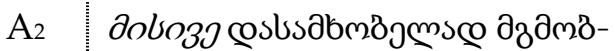

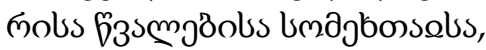

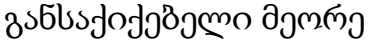

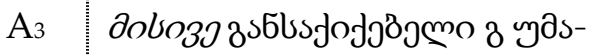

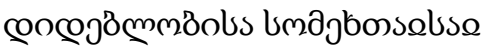
usaf̧anosmżousozl.

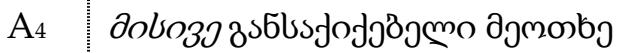
бзsмmöols umajborsebse.

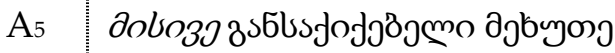
६зsmjäols umajbonselsse œs эुmamalssonzl

E aobo39, боzовs ambs bygols biygongmons ambslignolse lsontmä̈onoms

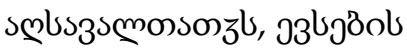

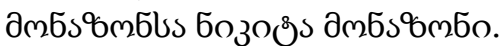

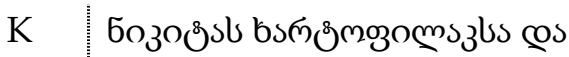

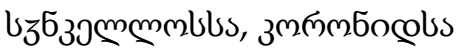

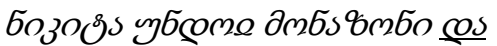
byajuo bryjongmons dmbstignolse, boomsoo

$\Psi$ бozogs ambsgmbols cos bugols brinconzmons ambstignols,

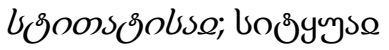

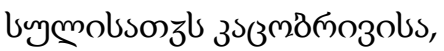

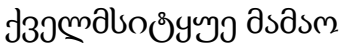

П аolozวlsamonbousonzls
The first speech on that shameful [and] false Armenian heresy by Nicetas, a monk and priest of the monastery of Studios, Stethatos

Destructively, on the false Armenian heresy, the second disgrace by the same.

The disgrace 3 on the Armenian Trisagion by the same.

The fourth disgrace on the Armenian heresy by the same.

The fifth disgrace on the Armenian heresy and unleavened bread by the same.

The same, Nicetas, a monk and priest of the Monastery of Stoudios, on the ladder of virtue; the monk Nicetas to the monk Eusebius.

Nicetas, a humble monk and priest of the Monastery of Stoudios, Stethatos to Nicetas, a chartophylax and syncellus, Coronis

The word on man's soul by Nicetas, a monk and priest of the Monastery of Stoudios, Stethatos, oh virtuous orator father

On paradise by the same. 


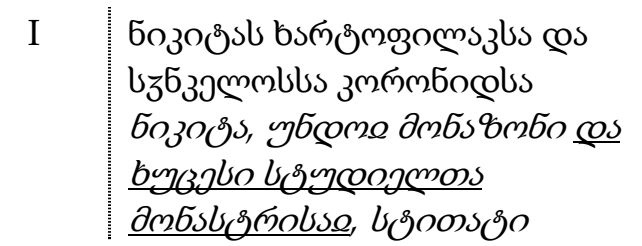

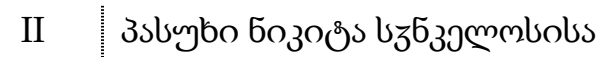
cos bs змпмбосоobse

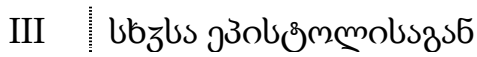

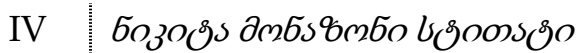

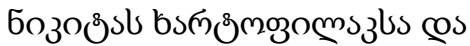

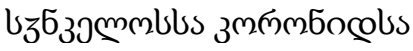

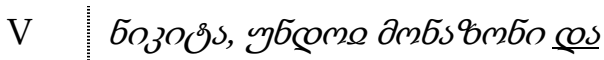
byaglo bizycongmons ambst-

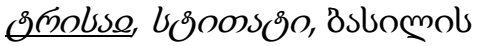

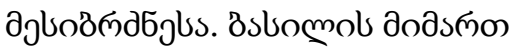

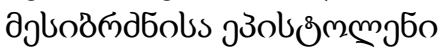

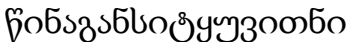

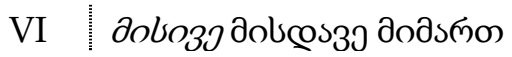

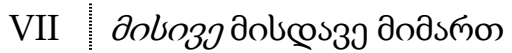

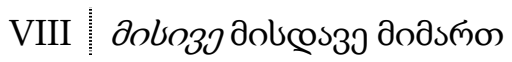

IX aobozว ठsbomol anasmon am5s\%mbols. Bsbomols

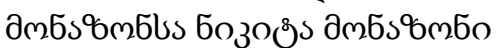

Nicetas, a humble monk and priest of the Monastery of Stoudios, Stethatos, to Nicetas, a chartophylax and syncellus, Coronis

Answer of Nicetas, a syncellus and chartophylax, Coronis

From another letter

Nicetas, a monk, Stethatos, to Nicetas, a chartophylax and syncellus, Coronis Nicetas, a humble monk and priest of the Monastery of Stoudios, Stethatos to Basil the Sophist. Epistles against Basil the Sophist

From the same to the same

From the same to the same

From the same to the same

From the same to the Monk

Basil. The Monk Nicetas to the Monk Basil

Here we can see, that not only Epistles I-VIII, but the whole set of Stethatos' works, collected in the Dogmatikon, follows the strict logic of the arrangement, when the first heading in a group contains a full title of Nicetas, i. e. "Nicetas, a [humble] monk and priest of the Monastery of Stoudios [, Stethatos]," and subsequent headings within the same group contain just "the same," or the shortened form "the monk Nicetas [Stethatos]" (in any case, they do not contain "priest of the Monastery of Stoudios"). In line with this feature, the works of Stethatos are grouped in the following sets in the Dogmatikon:

1. Words against Armenian anti-Chalcedonianism;

2. Letter to Eusebius; 
3. Letter to Nicetas Chartophylax;

4. The treatises "On the Soul" and "On Paradise;"

5. Correspondence between Nicetas Stethatos and Nicetas Chartopylax (Epistles I-IV);

6. Letters from Stethatos to Basil the Sophist (Epistles V-VIII) and Basil the Monk (Epistle IX).

Consequently, Epistle IX to Basil the Monk does not open a new group of Nicetas' letters (i.e., a new addressee), but belongs to the same group as Epistles V-VIII to Basil the Sophist. It is worth mentioning here that the arrangement of Nicetas Stethatos' works in the Dogmatikon matches the change of addressees. ${ }^{25}$

\subsection{Formal Compliments and Stethatos' Tone to the Addressee}

With regard to Stethatos' attitude to his addressees, we assume that, even if something would have happened in the course of the correspondence, it is unlikely that Nicetas Stethatos would have substantially changed his attitude and basic treatment of the same person. Thus, if Basil the Monk is the same person as Basil the Sophist, we should find traces of the same attitude in Nicetas' letters, despite a possible change in his mood, in the course of the correspondence. ${ }^{26}$ Let us examine Stethatos' attitude to all his addressees.

Stethatos treated Nicetas Chartophylax quite frankly and friendly, placing emphasis on the clerical rank of the addressee:

\begin{tabular}{|c|c|c|}
\hline I and IV.10 & 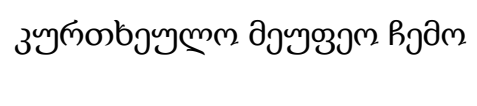 & $\begin{array}{l}\text { my pious [Reverend] } \\
\text { Lord }\end{array}$ \\
\hline IV.Preamble & 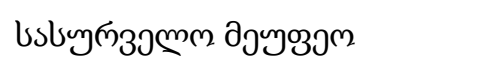 & dear [Reverend] Lord \\
\hline IV.Preamble & 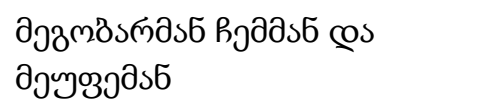 & $\begin{array}{l}\text { my friend and [Rev- } \\
\text { erend] Lord }\end{array}$ \\
\hline
\end{tabular}

With regard to Nicetas' attitude towards Basil the Sophist, we observe that, despite all skepticism and even attacks, Nicetas treated him quite politely (at least formally), putting all the stress on the addressee's intellect: ${ }^{27}$

(25) The same is not true for the Greek versions (see $\S 5.1$ below).

(26) RAPHAVA, "Georgian Translations," pp. 259-260.

(27) It does not matter here whether it was ironical or not. 


\begin{tabular}{|c|c|}
\hline I & зобау д๓дэбольљธо \\
\hline V.2 & 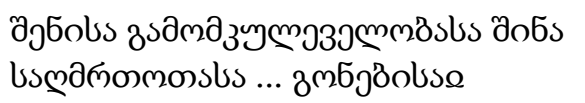 \\
\hline V.3 & 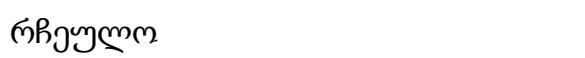 \\
\hline V.12 & 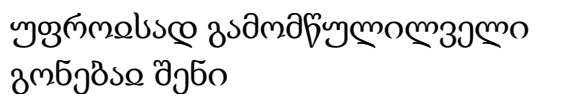 \\
\hline VI.1 & 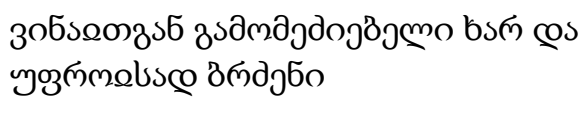 \\
\hline VII.1 & 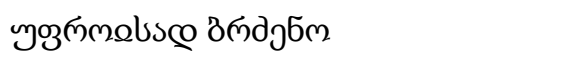 \\
\hline VII.6 & 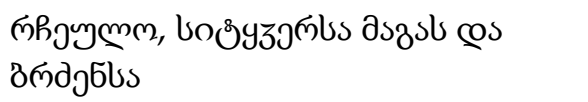 \\
\hline VIII.1 & 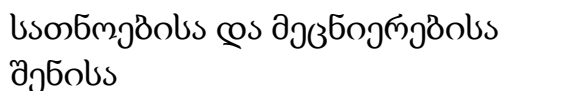 \\
\hline
\end{tabular}

somebody from the wise ones in your mind, [gifted in ability] to study [all the] divine one of the elite your most refined mind

who art researcher and the most wise one

the most wise one one of the elite of speech and wisdom to your virtue and knowledge

It is remarkable that there is no difference in Stethatos' attitude to the Sophist, regardless of whether a letter is addressed directly to the Sophist (V-VIII) or whether Nicetas discusses the Sophist with Nicetas Chartophylax (I).

Stethatos also treated Basil the Monk politely and underlined the addressee's intellect as he did with the Sophist: "thy prudence surprised me greatly" (IX.1), "thou, who art a servant of the Word" (IX.2). ${ }^{28}$ With regard to the latter one, the phrase "a servant of the Word" also appears in Epistle IV, where Stethatos uses it for Paul the Apostle and Dionysius the Areopagite, emphasizing that "they possess precedence in theology, because they were taught from the Word of God" (IV.1). Since it is unlikely that Nicetas valued Basil the Monk's knowledge at the same level as that of Paul the Apostle and Dionysius the Areopagite, the phrase "servant of the Word," when applied to Basil, refers to his clerical rank, but should be considered as nothing more than formal politeness or even irony.

Stethatos' attitude towards Eusebius in Epistle E is neutral, without offering a specific treatment of the addressee. This differs from

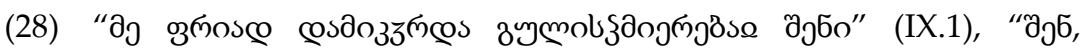

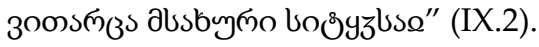


his treatment of all other addressees-Nicetas Chartophylax, Basil the Sophist, and Basil the Monk.

Therefore, Epistles V, VI, VIII and IX contain similar formal compliments to the addressee and there is no sufficient contrast between Basil the Sophist and Basil the Monk with regard to the attitude shown to them by Nicetas Stethatos. Yet both can be clearly distinguished from Nicetas Chartophylax and Eusebius.

\subsection{Conclusion}

Our observations give us a plausible basis to conclude that the addressee of Epistle IX is Basil the Sophist, the same person as the addressee of Epistles V-VIII. Since Basil is mentioned as the Monk in the title of Epistle IX, we assume that Basil the Sophist took monastic vows during the period between the writing of Epistle VIII and IX.

\section{THE SOPHIST: BASIL OR GREGORY?}

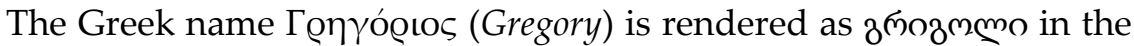

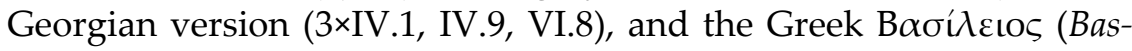
il) - as Bsbomo (IV.9, 2×VI.8, VI.10). The only exception is the name of the Sophist, which is Gregory in the Greek editions (V.Title, VI.10), and Basil in the Georgian version (III, V.Title, VI.10). ${ }^{29}$

From a paleographical perspective, Basil instead of Gregory could appear in the Georgian version if it rendered zюовме- with the contraction $\overline{\bar{T}} n-$ in this case we can assume a corruption of the text

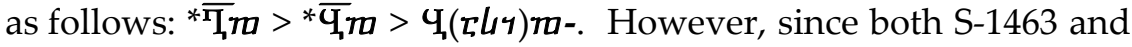
K-23 render Gregory and Basil in full, and the Sophist is named Basil everywhere (in the forms yrLฯm- and Y,CUT'b-), this would require multiple corruptions of contractions that happen not gradually, from one copy of the Dogmatikon to another, but already in the common protograph of S-1463 and K-23, which is unlikely..$^{30}$ Moreover, even if we accept such a possibility, the identical simultaneous corruption in three different places of the protograph, written in different scripts, seems to be completely impossible, especially counting the fact, that in all other places of the epistles (while mentioning the holy fathers) there are no problems with rendering Basil (four times) and Gregory

(29) RapHAVA, “Georgian Translations," pp. 250-251.

(30) On the possible protograph of the manuscripts K-23 and S-1463, see above $(\S 2.2)$. 
(five times). Thus, the nature of this difference between the Georgian and Greek versions should be explained differently: either Arsen replaced Gregory with Basil intentionally, or the Sophist was called Basil in the Greek manuscript Arsen used.

We think that an intentional replacement of the Sophist's name by Arsen Iqaltoeli should be excluded, because such a handling of text is completely foreign to the translation principles of Arsen, who did not offer corrections even for obvious errors (or slips) in Biblical quotations. ${ }^{31}$ It would be illogical to suppose that such a meticulous translator arbitrarily replaced the name of one of the correspondents, which would have to be regarded as less important than the correct rendering of biblical passages.

Therefore, we suppose that the variation in the Sophist's name between the Greek and Georgian versions had to have originated in the variation of the Sophist's name in the early Greek manuscripts. Since the Sophist and the Monk are the same person (see §3), we assume that the variation of the names Basil : Gregory for the Sophist may reflect the use of his secular and clerical names. ${ }^{32}$ All of these can shed some light on the figure of the Sophist and help to establish his identity. ${ }^{33}$

\section{THE CORRELATION BETWEEN THE GEORGIAN AND GREEK EDITIONS}

\subsection{Arrangement of the Epistles in the Georgian and Greek Editions}

Both the Georgian and Greek versions contain the epistles arranged not in true chronological order, but by addressee. However, there are some differences in the titles of Epistles I-VIII (IX) in the Greek and Georgian versions:

(31) RAPHAVA, “Georgian Translations," p. 251.

(32) Another possibility, which we cannot exclude completely, is simply a variation in the attribution of the epistles in the Greek versions. However, this is unlikely, because the Sophist's name in Stethatos' letters to the Sophist matches his name in Chartophylax' letter to Stethatos.

(33) The recently discovered unknown version of Epistle III may help in establishing the identity of Sophist. This will be discussed in a forthcoming article (see n. 23 above). 
Georgian $^{34}$

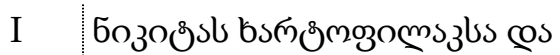

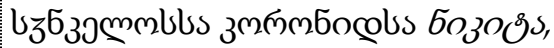
ybsome dmbs bmbo cos by usycongmons dmbsts bुoonsoo

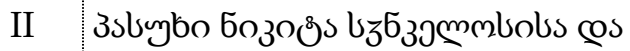

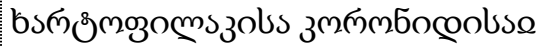

III ubzls j3obsemmobszs6

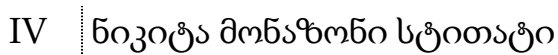

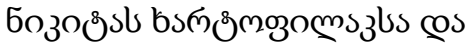

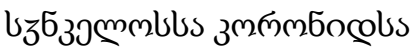

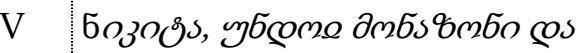
bygju bsignojmons dmbstonolse, bsoosiono, Bslomols

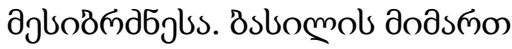

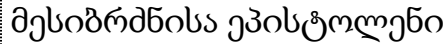

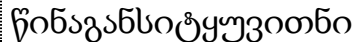

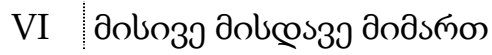

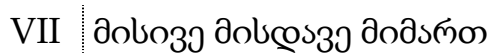

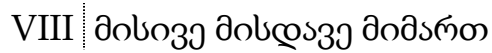

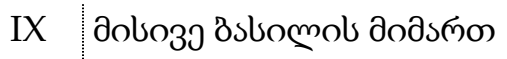
ambs\%mbols. Bslomols

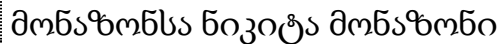

Greek

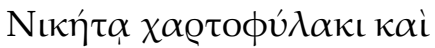

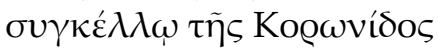

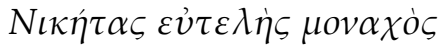
$\kappa \alpha i \pi \rho \varepsilon \sigma \beta \dot{v} \tau \varepsilon \rho o \varsigma \mu o v \tilde{\eta} \varsigma \tau \tilde{\omega} v$

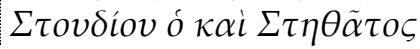

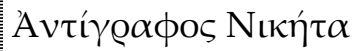

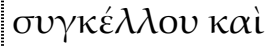

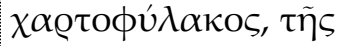
Kogwvídos

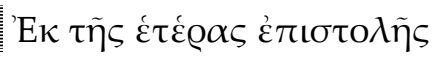

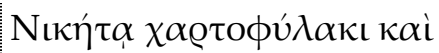

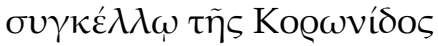

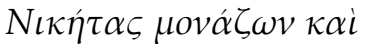
$\pi \rho \varepsilon \sigma \beta \dot{v} \tau \varepsilon \rho o \varsigma \mu о v \tilde{\eta} \varsigma \tau \tilde{\omega} v$

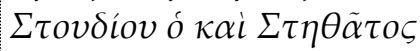

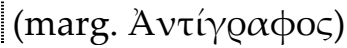

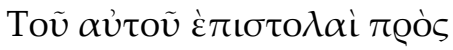

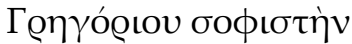

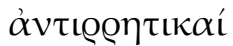

T $\tilde{\omega} \alpha \dot{v} \tau \tilde{\omega}$

$\mathrm{T} \tilde{\omega} \alpha \hat{v} \tau \tilde{\omega}$

T $\tilde{\omega} \alpha \hat{v} \tau \tilde{\omega}$

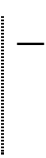

As we can see, Nicetas Stethatos' full title can be found in the titles of Epistles I and IV in the Greek editions, and the titles of Epistles I and V in the Georgian version. Since Stethatos' full title opens a new block of works (§ 3.2), this textual difference points to a difference in the principles of the arrangement of the epistles between the Greek

(34) For the translation, see the full list of works of Nicetas in § 3.2. 
and Georgian versions. In the Georgian edition, the epistles are grouped according to the addressee's identity: the first block includes the correspondence between Stethatos and Chartophylax (I-IV), while the second one includes letters from Stethatos to Basil (V-IX). In the Greek editions the epistles are grouped according to their didactic value: the first block includes the personal correspondence between Stethatos and Chartophylax (I-III), that does not deal with theological issues, while the second block includes all the didactic epistles by Stethatos (IV-VIII), regardless of the addressee's identity (Epistle IV to Chartophylax is grouped with Epistles V-VIII to Basil). The Greek title of Epistle V (the first letter to the Sophist) does not contain even the name of its author, and it cannot be attributed by itself, outside of the single block with Epistle IV.

Obviously, the arrangement of the epistles in the Dogmatikon should be primary, while the rubrication of the epistles in the Greek versions is a piece of evidence for their later rearrangement, retaining the same order of the epistles. This conclusion is also supported by the marginal note " $\alpha v \tau$ í found in the Greek versions only. Such a clarification, made by a scribe or an editor, ${ }^{35}$ is excessive if Epistles III and IV belong to the same group of epistles. Yet it becomes necessary when Epistle IV is detached from Epistle III and placed in a different group.

\subsection{The Nature of the Differences between the Editions}

The difference between Georgian $\partial g l s \partial g l s s$ (third) and Greek $\pi \rho \dot{o}$ $\tau \alpha v i \tau \varsigma$ (previous) in the Epistle VIII to the Sophist ${ }^{36}$ originates from the rearrangement of the epistles in the Greek edition. Chronologically Epistle VII is the third letter to the Sophist. ${ }^{37}$ Thus, the word third in the Georgian text of Epistle VIII constitutes a completely natural reference to Epistle VII. However, such a reference back to Epistle VII does not cause confusions, only if this epistle is the third one in its group of letters. We have such a situation only in the Georgian edi-

(35) If the remark $\dot{\alpha} v \tau i \gamma \rho \alpha \phi o \varsigma$ was present initially, we should have had to expect it in a title and not in a marginal comment (cp. the title of Epistle II, containing $\dot{\alpha} v \tau i \gamma \rho \alpha \phi o \varsigma)$.

(36) RAPHAVA, “Georgian Translations,” p. 250.

(37) This follows from the order of the epistles, as well as from the direct words of Nicetas about Epistle VII as the third epistle to the Sophist (VII.1). 
tion, while in the Greek editions Epistle VII is the fourth letter in its block and pointing to it with the word third from Epistle VIII had to cause confusion.

For the Georgian version there is no difference between the readings previous and third, as neither of the two requires any elucidations. The reading $\pi$ @ò $\tau \alpha \boldsymbol{v} \tau \eta \boldsymbol{\varsigma}$ is obviously easier for the Greek version than a hypothetical ${ }^{*} \tau \varrho i ́ \tau \eta$. Based on the principle of lectio difficilior potior, we can draw the conclusion that third in the Georgian version is a correct rendering of the original text of Nicetas Stethatos, while previous in the Greek version is a corruption of the text, which occurred after the epistles were regrouped in the Greek edition. This conclusion agrees with already existing studies of the Dogmatikon, which reveal that the Georgian version contained in the Dogmatikon is closer to the original text of Nicetas Stethatos than the Greek manuscripts known nowadays. ${ }^{38}$

\subsection{Absence of Epistle IX from the Greek Editions}

As pointed out above, Epistle IX chronologically precedes Epistles IIV. Thus, it precedes the compilation of the collection of epistles as well as the creation of the colophon. Its absence in the Greek editions as well as its separate position in the Dogmatikon seem to be obscure, because the epistle's title implies its inclusion in one section with other epistles to Basil (see $\S 3.2$ above). This question requires further research and could be connected to the identity of the Sophist and existing variations of versions of Epistle III. ${ }^{39}$

\section{SUMMARY}

Based on our study, we can draw the following conclusions:

1. According to the colophon that is retained in the Georgian translation, the collection of Nicetas Stethatos' treatises and epistles was compiled in January 1080 by Stethatos himself.

(38) M. KASRADZE-GIROD, La traduction géorgienne ancienne des écrits de Nicétas Stéthatos dans le «Dogmatikon» d'Arsen d'Iqaltho, XIe siècle, École pratique des hautes études, Section des sciences historiques et philologiques,

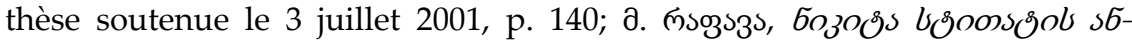

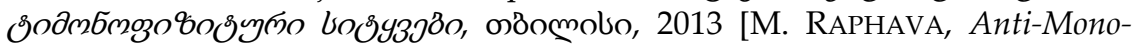
physite Speeches by Niketas Stethatos, Tbilisi, 2013], pp. 30-31.

(39) See n. 23 and n. 33 above. 
2. The marginalia at the colophon of the Georgian manuscripts of the Dogmatikon have to be attributed to Arsen Iqaltoeli himself.

3. Basil the Sophist and Basil the Monk is the same person, who, most probably, took monastic vows during the time between the writing of Epistle VIII and Epistle IX by Nicetas Stethatos.

4. The Greek versions of Nicetas' epistles show traces of the later work of the editor.

The cause for the absence of Epistle IX in the Greek versions and the identity of the Sophist continue to remain unclear. 